\title{
The Determinant Factors in Using E-Samsat Services on Motorized Vehicle Tax Payment in East Java, Indonesia
}

\author{
Rita Ambarwati $^{1 *}$; Mudji Astuti ${ }^{2}$, Rohman Dijaya ${ }^{3}$; Retna Fetty Idamayanti ${ }^{4}$ \\ ${ }^{1-2}$ Master of Management, Faculty of Business Law Social Science, Universitas Muhammadiyah Sidoarjo \\ Jln. Mojopahit No.666, Jawa Timur 61215, Indonesia \\ ${ }^{3}$ Computer Science, Faculty of Science and Technology, \\ Universitas Muhammadiyah Sidoarjo \\ Jln. Mojopahit No.666, Jawa Timur 61215, Indonesia \\ ${ }^{4}$ Master of Management Technology, Institut Teknologi Sepuluh Nopember Surabaya \\ Jln. Teknik Kimia, Jawa Timur 60111, Indonesia \\ ${ }^{1}$ ritaambarwati@umsida.ac.id; ${ }^{2}$ mudjiastuti@umsida.ac.id; \\ ${ }^{3}$ rohman.dijaya@umsida.ac.id; ${ }^{4}$ mayadipendajatim@gmail.com
}

Received: $12^{\text {th }}$ June 2020/ Revised: $31^{\text {st }}$ August 2020/ Accepted: $30^{\text {th }}$ September 2020

How to Cite: Ambarwati, R., Astuti, M., Dijaya, R., \& Idamayanti, R. F. (2021). The Determinant Factors in Using E-Samsat Services on Motorized Vehicle Tax Payment in East Java, Indonesia. Binus Business Review, 12(1), 53-61. https:// doi.org/10.21512/bbr.v12i1.6496

\begin{abstract}
E-Samsat offers the service regarding motorized vehicle tax payment online. Still, in its implementation, it does not have many users. It is due to the community's lack of awareness and the advantages that it can offer. The research aimed to analyze the determinant factors in using the e-Samsat service in East Java. The effects of each variable (trust, awareness, ease of use, and intention to use) on each other were examined. The research was conducted at Samsat joint office in Surabaya because it was the area with the largest motorized vehicle in East Java. The research applied a quantitative approach. There were 200 respondents who were users of the service. They were selected using the cross-section technique through questionnaires. Then, data analysis used the Partial Least Square Structural Equation Modeling (PLS-SEM) approach. Data analysis results indicate that almost all hypotheses are acceptable and have a significant effect on each other. However, trust does not have a significant effect on the intention to use. The analysis of these factors can be recommended to increase the acceptance of e-Samsat services in East Java. The research can help the government to make decisions related to e-government, create technological innovations that facilitate payments, and improve e-Samsat services quality.
\end{abstract}

Keywords: intention to use, e-Samsat services, motorized vehicle tax payment

\section{INTRODUCTION}

The services have several meanings depending on the area of expertise and the point of view in defining them. Although service development is not new, the extent to which information and communication technology facilitates the acceleration of a new service always grows. Many companies have moved or planned to move their traditional services to electronic services. It is essential to know the characteristics of each electronic service and evaluate it (Kvasnicova, Kremenova, \& Fabus, 2016). As a form of providing excellent service and seeing the demands of modern society, the use of information technology (information and communication technology innovations) has influenced citizens' behaviors. It is first used for communication and service provision with the Internet (Gasova \& Stofkova, 2017). However, it is more developed now. Some examples of electronic services (e-services) are e-government, e-learning, and e-commerce. An e-service is an Internet service in which purchases and sales can be made online. In contrast to traditional services, e-service is a web-based service provided through the Internet (Kvasnicova et al., 2016).

The Regional Revenue Agency in East Java 
provides the community with facilities, infrastructure, and other tools related to regional tax collection, specifically the payment of motorized vehicle tax. These payments are regulated by Presidential Regulation Number 5 of 2015 regarding Sistem Administrasi Manunggal Satu Atap (Samsat - OneStop Administration Services Office) for motorized vehicles. Electronic Samsat (e-Samsat) is an innovation for motorized vehicle tax payments and road traffic accident donations in East Java. The services in e-Samsat can be done for 24 hours non-stop, and the payment can use various banks. The banks can be Bank Mandiri, Bank Negara Indonesia (BNI), Bank Rakyat Indonesia (BRI), Bank Jatim, and Bank Tabungan Negara (BTN). Moreover, the ratification of Surat Tanda Nomor Kendaraan (STNK - Vehicle Registration Certificate) can also be done using the application. E-Samsat has been created as an option by providing the convenience for annual motorized vehicle tax payment. The payments are made in noncash through bank services. Hence, it eliminates the service-related complaints from consumers and minimizes the existing problems. The problems can be complex processes, extra costs like buying file folders and photocopying, and brokers.

The condition in e-Samsat in East Java has not had a very significant contribution to locally-generated revenue yet. It was only around $0,0-0,18 \%$ until 2019. The lack of introduction of e-Samsat and its benefit to the community shows the low level of acceptance of the services, although it is the digitization of government services. There is a need for research that measures the technology acceptance in the community regarding e-Samsat. Some reasons for low acceptance may be that online services are unsatisfying and do not provide adequate investment returns (Abu-Shanab, 2017).

The research is conducted to analyze the factors that influence the intention to use e-Samsat in East Java. The result will be used as the recommendations to the government to improve e-Samsat services by developing third-party cooperation. The third-party affiliations can be retail outlets or Payment Point Online Banking (PPOB). The government should use analytical material because it needs high costs or investments in developing information technology. It should look at the minimized cost so it can continue to enhance services.

The previous research analyzes the application of e-government services with trust and personal value variables (Prior, Mazanov, Meacheam, Heaslip, \& Hanson, 2016). It also integrates trust in Technology Acceptance Model (TAM) due to the online context with time awareness and environmental concern as mediating variables. Another previous research also examines the mediation role, namely the awareness of taxpayers about the relationship between tax socialization, tax knowledge, benefits of tax identity numbers, service quality, and tax compliance. Using path analysis, it shows that the awareness of taxpayers has full mediation in the benefits of tax identity, tax quality, and taxpayer's compliance. In contrast, awareness of taxpayers does not have a mediating role in the relationship of tax socialization, tax knowledge, and tax payments (Andreas \& Savitri, 2015). These variables will be mapped in the research.

Trust is the act of recognizing that something is right or wrong. It is considered the hope and promise of a trustworthy person or group (Fakhoury \& Aubert, 2015). There are two dimensions of the measurement of trust in an e-government context: trust in a particular entity (government) and the technological reliability of the Internet (Buffat, 2015). In outstanding public service companies, modern information systems are useful to improve efficiency and support more efficient work processes. The tasks and work will be facilitated by the trust in an information technology organization (Das, Singh, \& Joseph, 2017). In this matter, the management needs to rely on new information system technology to evaluate individuals' performance so that new computer-based systems can control the performance of public services (Widodo, Irawan, \& Sukmono, 2019). The effectiveness of entity's information system depends on how the system works (Mensah, 2018). This information system must simplify the design and technology that it offers. The high evaluation value for the implementation of the technology is not only caused by the system properties but also the system security. Then, the conceivable development program will satisfy and meet consumers' needs (Gasova \& Stofkova, 2017).

Previous research uses trust as the factor in affecting people's intention to use e-government services (Chatzoglou, Chatzoudes, \& Symeonidis, 2015). The results show that the perceived usefulness of e-government services is the primary driver. The other essential factors include confidence, Internet knowledge, peer influence, machine efficiency, and perceived risk. Hence, the researchers propose the hypotheses as following:

\section{H1 : Trust has a positive effect on awareness,}

\section{H2 : Trust has a positive effect on ease to use,}

\section{H3 : Trust has a positive effect on intention to use.}

Next, awareness is people's experience when embracing technology. It is in the form of user awareness. Consumers must be more mindful in considering integral factors in the adoption of modern electronic systems. Related to this, three factors play a significant role in identifying new strategies: internet knowledge, information technology experience, and internet comprehension. For example, the mobile government is in developing progress in Saudi Arabia. Hence, the previous research examines the possible factors affecting the adoption of mobile government services in Saudi Arabia. The analysis shows that confidence, usage experience, awareness, and security factors can influence the implementation of mobile government services in Saudi Arabia (Alotaibi, Houghton, \& Sandhu, 2016). 
Further investigation also shows the factors affecting the use of internet banking services. The previous researchers use eleven variables in their test: accessibility, compatibility, usability, power, social impact, reliability, risk, website functionality, alliance resources, service, and the personal knowledge of how internet banking is used. Compatibility has a significant effect on Internet banking (Mathiyarasan \& Chitra, 2019). Moreover, previous research also explores the mediation role, such as taxpayers' understanding of tax socialization, the benefit of tax identification numbers, service quality, and taxpayer enforcement. The results show that taxpayers' awareness is fully mediated for the interests of tax identity, tax quality, and compliance. Conversely, taxpayers' awareness has no mediating role in the relationship between tax and tax socializations (Andreas \& Savitri, 2015). Then, the next proposed hypotheses are:

\section{H4 : Awareness has a positive effect on intention to use,}

H5 : Awareness has a positive effect on ease to use.

The ease of use can be promoted in the context of a procedure or operation. The previous research uses the facility variable and examines the mediating effect of perceived ease of use on the connection between tax services quality and the online tax system. The perception of ease of use has a substantial mediating effect between the quality of tax services and the online tax system. Meanwhile, the quality of tax services has a strong positive relationship with the online tax system. This previous research aims to understand how an electronic tax system can effectively improve tax enforcement and generate income (Mustapha \& Obid, 2015).
Moreover, the concepts of confidence, usability, and convenience seem to explain many of the website's practical methods, as mentioned by Mota, Bellini, Souza, and Oliveira (2016). These factors also define how far they influence the use of biometric election of government websites in Brazil. In this matter, the perceived usefulness and ease of use have a significant effect on average. Only the confidence dimension in government affects all levels of consumption.

The positive influence of technology advancement in today's circle will promote knowledge and work, depending on how people use technology to benefit others. On the one hand, there are also negative impacts, particularly adolescents who are misusing this technology. Related to this, the use of technology is only for personal purposes (Pitchay Muthu Chelliah, Thurasamy, Alzahrani, Alfarraj, \& Alalwan, 2016). The previous research indicates that to use e-government services. People may include performance expectations, corporate expectations, social impact, quality of knowledge, system efficiency, and service quality (Onu \& Oats, 2018). Then, the use of technology in an organization's information system should consider whether or not technology can be utilized through user tasks and abilities (Carter, McFadden-Wade, \& Wells, 2016). In this analysis, the conceptual structure in Figure 1 will resolve the issue. Besides, the data analysis results can provide advice on improving e-Samsat services in East Java. Hence, it will increase the number of objects based on system quality, information quality, and web service quality in e-Samsat. Hence, the last hypothesis is as follows.

H6 : Ease to use has a positive effect on intention to use.

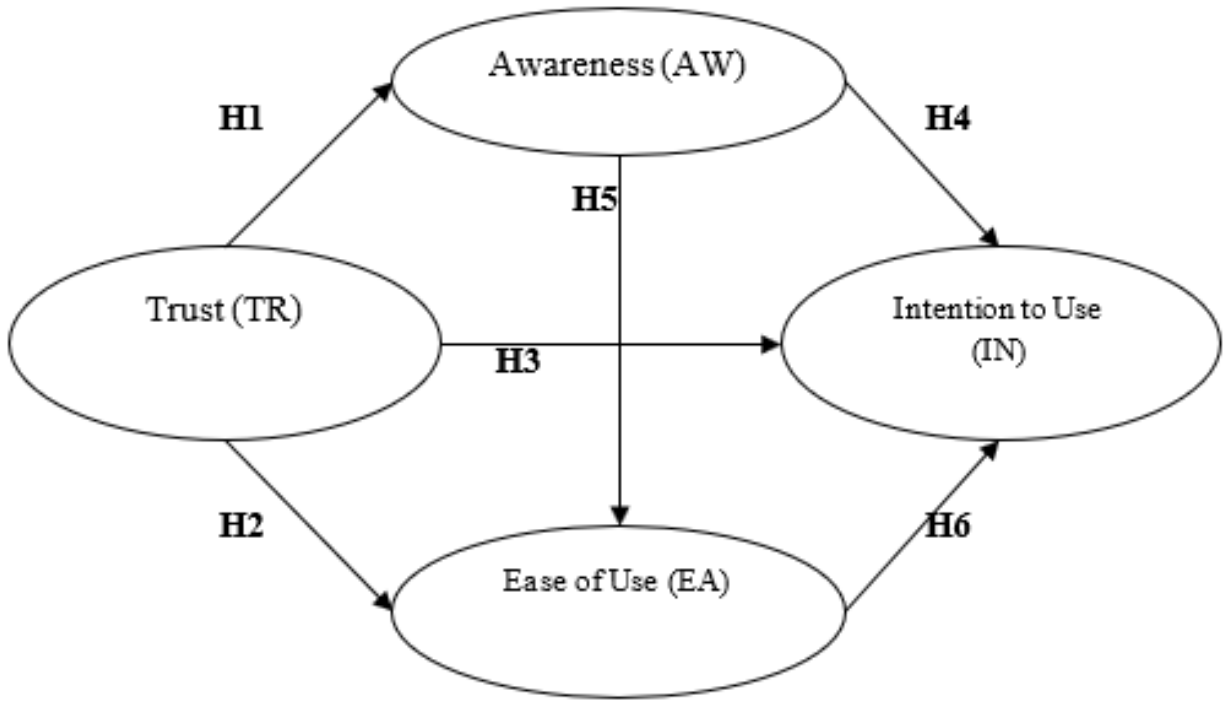

Figure 1 Research Concepts and Hypothesis 


\section{METHODS}

The research applies a quantitative approach. The used research design is cross-sectional. It collects data one time to measure the behavior of several populations through a sample of several variables. The results have the advantage of providing information in a short time.

The research is conducted at Samsat joint office in Surabaya because it is the area with the largest motorized vehicles in East Java. The e-Samsat office in Surabaya covers the eastern, western, northern, and southern areas of East Java. The method of distributing questionnaires is by giving them to the users of e-Samsat in front of the counter when they exchange the proof of tax payment.

In determining the minimum sample size, the researchers refer to the number of used indicators in the questionnaires. It is by assuming $\mathrm{n} \times 5$ observed variables up to $n \times 10$ observed variables. Hence, the minimum number of respondents is 105 . The research obtains 200 respondents. The population is the users of the e-Samsat services in the Samsat joint office in Surabaya.

The Likert scale is used in the questionnaire due to several considerations. First, it is convenient. Second, it has high reliability in sorting subjects based on perception. Last, it is more flexible compared to other techniques and applicable in various situations. The scales are 5 for very satisfied, 4 for satisfied, 3 for neutral, 2 for dissatisfied, and 1 for very dissatisfied. Then, the data are analyzed using Partial Least Square Structural Equation Modeling (PLS-SEM) approach. The research uses the analysis tool of WarpPLS 5.0 in processing data and statistical methods that describe the questionnaire data. Path analysis is also carried out to determine the significance of the effect and variable relationships.

\section{RESULTS AND DISCUSSIONS}

The respondents are 200 users of e-Samsat service in the Samsat joint office in Surabaya. The details are in Table 1. Based on the results, 12 respondents are 18-25 years old (6\%). It is followed by $26-35$ years ( 73 respondents or 36,5\%) and 46-60 years (32 respondents or 16\%). Most respondents are $36-45$ years old ( 83 respondents or $41,5 \%$ ). The result illustrates that most of the e-Samsat users are adults. They agree that using information and communication technology can provide convenience in the digital era. Based on gender, most respondents are male (118 respondents or $59 \%$ ). Meanwhile, the female respondents are $82(41 \%)$. It shows that e-Samsat users are most dominated by men who are the backbone of the family.

Based on occupation, 30 respondents (15\%) work as civil servants, army, or police. Meanwhile, the respondents who are private employees are 55 $(27,5 \%)$. Then, there are 46 entrepreneurs $(23 \%)$. However, most respondents (63 respondents or $31,5 \%$ ) work other than the previously mentioned jobs. They can be housewives, contract workers, honorary staff, and others. Meanwhile, the smallest number of respondents is the student ( 6 respondents or 3\%).

Table 1 Data of the Respondents

\begin{tabular}{clcc}
\hline No. & Characteristics & Total & $\mathbf{\%}$ \\
\hline 1. & Age (years) & & \\
& $18-25$ & 12 & 6 \\
& $26-35$ & 73 & 36,5 \\
& $36-45$ & 83 & 41,5 \\
& $46-60$ & 32 & 16 \\
2. & & \\
& Mender & 118 & 59 \\
& Female & 82 & 41 \\
3. Job & & \\
& Civil servant/ army/ police & 30 & 15 \\
& Private employee & 55 & 27,5 \\
& Entrepreneur & 46 & 23 \\
& Students & 6 & 3 \\
Others & 63 & 31,5 \\
\hline
\end{tabular}

Based on Table 2, in the validity test (2-tailed), all indicators except for EA2 and AW2 are valid ( $r$-count $>0,361)$. The indicators are invalid because of the r-count $<0,361$. Next, convergent validity with WarpPLS 5.0 is conducted by using the value of each indicator loading factor. The Average Variance Extracted (AVE) value should be above 0,50. The AVE values are 0,629 for trust, 0,501 for ease of use, 0,592 for awareness, and 0,618 for intention to use. It means that these variables have AVE values greater than 0,50. All of these variables have met the convergent validity requirements.

In addition, discriminant validity is the correlation coefficient between latent variables and their significance (p-value). The high value of discriminant validity indicates that a construct is unique. The cross-loading value must be more than 0,70 to test discriminant validity. Another way that can be used to test the discriminant validity is by comparing the square root of AVE for each construct with the correlation value between constructs in the model. The good discriminant validity is shown from greater square root AVE than the correlation between constructs in the model. Table 3 shows that the result of discriminant validity. It indicates that the AVE squared value is 0,793 for trust, 0,708 for ease of use, 0,769 for awareness, and 0,786 for intention to use. The results show greater values than the correlation between constructs in the model. Hence, the indicators have met the criteria for discriminant validity.

Then, a reliability test proves the accuracy or consistency instruments in measuring constructs. In PLS-SEM using the WarpPLS program, the reliability 
test can be done in two ways: Cronbach's alpha and the composite reliability. The Cronbach's alpha value in the confirmatory study should be more than 0,70 . Similarly, the composite reliability value must be more than 0,70 . According to Table 4, all indicators are reliable. Hence, the indicators can be used in the research.

The R-squared value shows how big the independent latent variables influence latent dependent variables. If the value is 0,70 , the model is strong. If it is 0,45 , the model is moderate. Meanwhile, if it is 0,25 , the model is weak. According to processing data with PLS-SEM, the results of the R-squared are in Table 5.

Table 5 shows that the influence of trust and awareness on ease of use provides an R-squared value of 0,431 . Here, the exogenous variables are trust and awareness. Meanwhile, the endogenous variable is the ease of use. It indicates that trust and awareness can explain the ease of use by $43,1 \%$. The value shows that the model is in the weak category. Similarly, the trust with awareness has R-squared value of 0,250 . The result means that the trust can explain the awareness by $25 \%$. The model is also in the weak category. The exogenous variable is trust, and the endogenous variable is awareness. However, the influence of trust, awareness, and ease of use on the intention to use is 0,565 . It indicates that the trust, awareness, and ease of use can explain the ease of use by $56,5 \%$. The model is in the moderate category with trust, awareness, and ease of use as exogenous variables and intention to use as an endogenous variable.

Table 2 The Results of Validity Test

\begin{tabular}{|c|c|c|c|c|}
\hline Variable & Indicator & R-Count & AVE & Information \\
\hline \multirow[t]{5}{*}{ Trust (TR) } & Website security (TR1) & 0,702 & 0,629 & Valid \\
\hline & Website reliability (TR2) & 0,641 & & Valid \\
\hline & Confidentiality of taxpayer data (TR3) & 0,752 & & Valid \\
\hline & The confidentiality of tax payment data (TR4) & 0,595 & & Valid \\
\hline & Website security from viruses or internet crimes (TR5) & 0,726 & & Valid \\
\hline \multirow{7}{*}{$\begin{array}{c}\text { Ease of Use } \\
\quad \text { (EA) }\end{array}$} & Easy to access the website pages (EA1) & 0,463 & 0,501 & Valid \\
\hline & Easy to use of the website (EA2) & 0,239 & & Invalid \\
\hline & Easy to understand website appearance (EA3) & 0,437 & & Valid \\
\hline & Easy to understand the menu on the website (EA4) & 0,698 & & Valid \\
\hline & The clarity of the menu on the website (EA5) & 0,664 & & Valid \\
\hline & The clarity of the steps in using the website (EA6) & 0,729 & & Valid \\
\hline & Sequential steps for using the website (EA7) & 0,691 & & Valid \\
\hline \multirow[t]{4}{*}{$\begin{array}{c}\text { Awareness } \\
(\mathrm{AW})\end{array}$} & $\begin{array}{l}\text { Use of the Internet network on the East Java e-Samsat } \\
\text { website (AW1) }\end{array}$ & 0,728 & 0,592 & Valid \\
\hline & $\begin{array}{l}\text { The accuracy of the tax fee information on the website } \\
\text { (AW2) }\end{array}$ & 0,028 & & Invalid \\
\hline & $\begin{array}{l}\text { The smoothness of getting payment code in the e-Samsat } \\
\text { website (AW3) }\end{array}$ & 0,471 & & Valid \\
\hline & Conformity of the smooth tax payment (AW4) & 0,533 & & Valid \\
\hline \multirow{5}{*}{$\begin{array}{l}\text { Intention to } \\
\text { Use (IN) }\end{array}$} & The usefulness of the East Java e-Samsat website (IN1) & 0,623 & 0,618 & Valid \\
\hline & Clarity of tax payment procedures (IN2) & 0,528 & & Valid \\
\hline & Clarity of the validation of the STNK (IN3) & 0,787 & & Valid \\
\hline & The ratification ease of the STNK (IN4) & 0,808 & & Valid \\
\hline & The adjustment of processing speed (IN5) & 0,723 & & Valid \\
\hline
\end{tabular}

Table 3 The Result of Discriminant Validity

\begin{tabular}{ccccc}
\hline & TR & EA & AW & IN \\
\hline TR & $\mathbf{( 0 , 7 9 3 )}$ & 0,547 & 0,484 & 0,535 \\
EA & 0,547 & $\mathbf{( 0 , 7 0 8 )}$ & 0,546 & 0,635 \\
AW & 0,484 & 0,546 & $\mathbf{( 0 , 7 6 9 )}$ & 0,652 \\
IN & 0,535 & 0,635 & 0,652 & $\mathbf{( 0 , 7 8 6 )}$ \\
\hline
\end{tabular}

Note: trust (TR), ease of use (EA), awareness (AW), and intention to use (IN)

(Source: Output of WarpPLS 5.0) 
Table 4 The Results of Reliability Test

\begin{tabular}{|c|c|c|c|c|}
\hline Variable & Indicator & Cronbach's Alpha & Composite Reliability & Information \\
\hline \multirow[t]{5}{*}{ Trust (TR) } & TR1 & 0,911 & 0,895 & Reliable \\
\hline & TR2 & 0,912 & & Reliable \\
\hline & TR3 & 0,909 & & Reliable \\
\hline & TR4 & 0,914 & & Reliable \\
\hline & TR5 & 0,910 & & Reliable \\
\hline \multirow[t]{7}{*}{ Ease of Use (EA) } & EA1 & 0,916 & 0,875 & Reliable \\
\hline & EA2 & 0,920 & & Reliable \\
\hline & EA3 & 0,917 & & Reliable \\
\hline & EA4 & 0,911 & & Reliable \\
\hline & EA5 & 0,912 & & Reliable \\
\hline & EA6 & 0,910 & & Reliable \\
\hline & EA7 & 0,911 & & Reliable \\
\hline \multirow[t]{4}{*}{ Awareness (AW) } & AW1 & 0,910 & 0,853 & Reliable \\
\hline & AW2 & 0,921 & & Reliable \\
\hline & AW3 & 0,915 & & Reliable \\
\hline & AW4 & 0,914 & & Reliable \\
\hline \multirow[t]{5}{*}{ Intention to Use (IN) } & IN1 & 0,912 & 0,889 & Reliable \\
\hline & $\mathrm{IN} 2$ & 0,914 & & Reliable \\
\hline & IN3 & 0,908 & & Reliable \\
\hline & IN4 & 0,907 & & Reliable \\
\hline & IN5 & 0,910 & & Reliable \\
\hline
\end{tabular}

Table 5 R-Squared Results

\begin{tabular}{lll}
\hline \multicolumn{2}{c}{ R-SQUARED } \\
\hline Ease of Use & 0,431 \\
Awareness & 0,250 \\
Intention to Use & 0,565 \\
\hline
\end{tabular}

(Source: Output of WarPLS 5.0)

Table 6 Q-Squared Results

\begin{tabular}{ll}
\hline & Q-SQUARED \\
\hline Ease of Use & 0,435 \\
Awareness & 0,250 \\
Intention to Use & 0,562 \\
\hline
\end{tabular}

(Source: Output of WarPLS 5.0)

In addition to looking at the R-squared value, the PLS model is also evaluated using Q-squared predictive relevance for the constructed model. Based on data processing with WarpPLS 5.0, the coefficient of determination (Q-squared) is generated in Table 6.

Q-squared is used to assess the predictive validity or relevance of a set of latent predictor variables in the criterion variable. The model with predictive validity must have a Q-squared value greater than 0 . Based on Table 6 , the results are 0,435 for ease of use, 0,250 for awareness, and 0,562 for intention to use. The values are more significant than zero. The results show that the model has predictive relevance that can explain the model of ease of use $(43,5 \%)$, awareness $(25 \%)$, intention to use $(56,2 \%)$.

The effect size value determines the proportion of certain exogenous variables on endogenous variables. There are three categories (Latan \& Ghozali, 2016). If the effect size value is $0,02-<0,15$, the latent predictor variable has a small effect. Then, the latent predictor variable with an intermediate impact is 0,15 $-<0,35$. Meanwhile, if the effect size value is $\geq 0,35$, it has a large influence. The results of the effect size value are in Table 7. Only trust on the intention to use is in the weak category $(0,074)$. In contrast, the other effect size values indicate the intermediate impact.

Table 8 shows the result of the hypotheses. The result of testing path coefficients implies that the trust directly affects awareness to use the e-Samsat services. Hence, H1 is accepted. The calculation shows that trust towards awareness has a significant $\mathrm{p}$-value with a path coefficient of 0,500 . The result is relevant to the previous research by Bwalya, Du Plessis, and Rensleigh (2014). They examined whether consumers (citizens and enterprises) knew the expected advantages of the e-government in the selected Zambia cities. In addition to traditional factors of user-friendliness and usefulness, they included additional factors, such as cultures, prices, confidence, and other social dimensions of beliefs. Although the acceptance of applications is an essential source of information systems research, few studies examine the 
history and effects of compulsory product adoption. They develop and monitor a mandatory acceptance model for e-government implementation (Rajiani \& Ismail, 2019). The previous research concludes that trust in institutions can increase awareness of the use of e-government technology.

There is a direct effect of trust on ease of use. $\mathrm{H} 2$ is accepted. The result of trust on ease of use has a significant $p$-value with a path coefficient of 0,384 . Trust has a significant influence on ease of use. The e-Samsat users trust the website to be safe and reliable. It will make e-Samsat services more comfortable to use. Lallmahomed, Lallmahomed, and Lallmahomed (2017) examined the history of e-government implementation in a small developing country. They indicated that expectations of performance, ease of use, and perceived interest were conduct-oriented. Technology efficacy shows a clear link to the behavioral purpose and aversion to change. This result also shows that trust is inversely linked to behavioral change. The website should be improved in terms of functionality and quality, focusing on security and confidentiality. Hence, the users will use e-Samsat more.

The trust cannot influence the intention to use e-Samsat significantly. H3 is rejected. The calculation shows that the effect of trust on the intention to use has an insignificant $p$-value of $0,026(>0,001)$ with a path coefficient of 0,134 . The results show that taxpayers trust e-Samsat because it provides data security and confidentiality. However, their trust does not affect the intention to use the e-Samsat service in reality. There is a need for further research on the intention to use without relying on trust but other factors in using the service. The result is not in line with Kurfalı, Arifoğlu, Tokdemir, and Paçin (2017) that taxpayers had trust and rely on information that could be accessed electronically. Still, there is a need for other variables to mediate the intention, such as awareness and ease of use.

There is a positive impact of awareness on the intention to use e-Samsat. So, H4 is accepted. The result shows the effect of awareness on the intention to use has a significant p-value. It means that awareness has a significant effect on the intention to use. Meanwhile, the path coefficient of the awareness on the intention to use is 0,398 . However, the consciousness of taxpayers has not achieved the anticipated point. The public is usually cynical and distrustful of charges because they often feel like in debt. Hence, they are burdened and continually struggled to pay. Moreover, they do not know how complex and confusing tax measurement and report are. The efforts still need to be made so people are fully aware of the tax payment. If people are aware of it, they will pay taxes willingly. The result is in line with Kayimbaşioğlu, Oktekin, and Haci (2016).

There is a positive and significant effect of awareness on ease of use. H5 is accepted. The $\mathrm{p}$-value of awareness on the ease of use is significant with the path coefficient of 0,367 . The result shows that e-Samsat contributors are aware of the need for accessible communication. This Internet network makes access to websites easier for taxpayers anywhere and anytime to increase their intention to use this service (Mathiyarasan \& Chitra, 2019). By increasing their awareness of e-Samsat services as an online service, they can use it easily.

Table 7 The Results of Effect Size Value

\begin{tabular}{lcc}
\hline Relationship & Value & Effect \\
\hline Trust $\rightarrow$ Ease of Use & 0,222 & Middle \\
Awareness $\rightarrow$ Ease of Use & 0,209 & Middle \\
Trust $\rightarrow$ Awareness & 0,250 & Middle \\
Trust $\rightarrow$ Intention to Use & 0,074 & Weak \\
Ease of Use $\rightarrow$ Intention to Use & 0,223 & Middle \\
Awareness $\rightarrow$ Intention to Use & 0,268 & Middle \\
\hline
\end{tabular}

(Source: Output of WarPLS 5.0)

Table 8 The Path Coefficients

\begin{tabular}{lccc}
\hline Variable & P-Values & Path Coefficient & Meaning \\
\hline Trust $\rightarrow$ Awareness & $<0,001$ & 0,500 & Significant \\
Trust $\rightarrow$ Ease of Use & $<0,001$ & 0,384 & Significant \\
Trust $\rightarrow$ Intention to Use & 0,026 & 0,134 & Insignificant \\
Awareness $\rightarrow$ Intention to Use & $<0,001$ & 0,398 & Significant \\
Awareness $\rightarrow$ Ease of Use & $<0,001$ & 0,367 & Significant \\
Ease of Use $\rightarrow$ Intention to Use & $<0,001$ & 0,339 & Significant \\
\hline
\end{tabular}

(Source: Output of WarPLS 5.0) 
Similarly, the ease of use affects intention to use e-Samsat significantly and positively. It has a significant p-value with a path coefficient of 0,339 . Hence, $\mathrm{H} 6$ is accepted. The result shows that e-Samsat users can quickly access the web. Then, it is easier for them to use the available services in e-Samsat. The users who regularly use the Internet have a clear desire and ability to use it (Pitchay Muthu Chelliah et al., 2016). The convenience of e-Samsat services will improve the intention to use.

The current situation shows the lack of public awareness of e-Samsat in East Java. Hence, there are not many users. Its information system quality can increase taxpayers' confidence and intention to use e-Samsat services. The quality of this system should meet the needs of users (Mathiyarasan \& Chitra, 2019). The next step is to educate taxpayers or people regarding this system.

Moreover, technically, private parties have maintained and improved the Internet network to support the infrastructure and maintain the system quality through collaboration with good Internet service providers (Suryanto, Setyohadi, \& Faroqi, 2016). The other factors that increase the intention to use are ease of use and awareness. The ease of use in e-Samsat services is shown by all details on the sum of tax value and the provided guideline. In short, the accuracy of the information system, frequent changes in records, and socialization regarding e-Samsat services are not equally distributed across all social levels. The service quality can be improved by making the service more useful to shorten payment processes via e-Samsat.

\section{CONCLUSIONS}

The research aims to measure the influence of several variables on the intention to use in e-Samsat services. Data analysis results indicate that almost all hypotheses are acceptable and have a significant effect on each other. However, trust does not have a significant effect on the intention to use. In trust, website reliability in tax payment is the dominant indicator that the management needs to consider. Meanwhile, for ease of use, the dominant indicator is the clarity of the stage sequence in the online tax payment process through the website. In awareness, the use of the Internet network in the e-Samsat website dominates the results. The consistent frequency of tax payment needs to be emphasized in improving e-Samsat services. Furthermore, if all primary interest indicators are more optimized, the intention to use e-Samsat services will increase.

The research can help the government to make decisions related to e-government, create technological innovations that facilitate payments, and improve e-Samsat services quality. The government can make binding policies and support the non-cash payment program from the regional revenue service of East Java. The government can also cooperate with a third-party non-cash payment technology as an electronic wallet to automate the manual banking payment process. The government should improve the infrastructure by replacing the manual system for exchanging motorized vehicle tax receipts with Android or iOS barcodes. The results can be implemented or developed in nonIndonesia countries with the same cultural patterns and grouped according to the users' age as several measured variables are from several Asian countries in the previous studies.

The research limitation is the researchers only focus on tax payments in e-Samsat. Further research can analyze other e-government services and measure e-government implementation performance. Future researchers can also add a mediation function between variables related to service performance and e-government implementation, including control, service quality, and risk. Furthermore, assessments are also needed to improve information and communication-based services.

\section{ACKNOWLEDGMENTS}

This work was supported by Basic Research grant from Universitas Muhammadiyah Sidoarjo in 2020. The authors are indebted to the Faculty of Business Law and Social Science at the Universitas Muhammadiyah Sidoarjo, which provided a grant to assist the research.

\section{REFERENCES}

Ajzen, I. (1985). From intentions to actions: A theory of planned behavior. In Action control (pp. 11-39). Springer.

Abu-Shanab, E. A. (2017). E-government familiarity influence on Jordanians' perceptions. Telematics and Informatics, 34(1), 103-113. https://doi. org/10.1016/j.tele.2016.05.001

Alotaibi, R., Houghton, L., \& Sandhu, K. (2016). Exploring the potential factors influencing the adoption of m-government services in Saudi Arabia: A qualitative analysis. International Journal of Business and Management, 11(8), 56-72. https://doi.org/10.5539/ ijbm.v11n8p56

Andreas, \& Savitri, E. (2015). The effect of tax socialization, tax knowledge, expediency of tax ID number and service quality on taxpayers compliance with taxpayers awareness as mediating variables. Procedia - Social and Behavioral Sciences, 211, 163169. https://doi.org/10.1016/j.sbspro.2015.11.024

Buffat, A. (2015). Street-level bureaucracy and e-government. Public Management Review, 17(1), 149-161. https://doi.org/10.1080/14719037.2013.77 1699

Bwalya, K. J., Du Plessis, T., \& Rensleigh, C. (2014). E-government implementation in Zambia Prospects. Transforming Government: People, Process and Policy, 8(1), 101-130. https://doi.org/10.1108/ TG-01-2013-0002

Carter, L., McFadden-Wade, G., \& Wells, J. T. (2016). Exploring the impact of organizational citizenship 
behavior on perceptions of e-filing success. International Journal of Public Administration in the Digital Age (IJPADA), 3(1), 43-52. https://doi. org/10.4018/ijpada.2016010103

Chatzoglou, P., Chatzoudes, D., \& Symeonidis, S. (2015). Factors affecting the intention to use e-government services. In Proceedings of the 2015 Federated Conference on Computer Science and Information Systems (pp. 1489-1498). https://doi. org/10.15439/2015f171

Das, A., Singh, H., \& Joseph, D. (2017). A longitudinal study of e-government maturity. Information \& Management, 54(4), 415-426. https://doi. org/10.1016/j.im.2016.09.006

Fakhoury, R., \& Aubert, B. (2015). Citizenship, trust, and behavioural intentions to use public e-services: The case of Lebanon. International Journal of Information Management, 35(3), 346-351. https:// doi.org/10.1016/j.ijinfomgt.2015.02.002

Gasova, K., \& Stofkova, K. (2017). E-government as a quality improvement tool for citizens' services. Procedia Engineering, 192, 225-230. https://doi. org/10.1016/j.proeng.2017.06.039

Kayimbaşioğlu, D., Oktekin, B., \& Haci, H. (2016). Integration of gamification technology in education. Procedia Computer Science, 102, 668-676. https:// doi.org/10.1016/j.procs.2016.09.460

Kurfalı, M., Arifoğlu, A., Tokdemir, G., \& Paçin, Y. (2017). Adoption of e-government services in Turkey. Computers in Human Behavior, 66(January), 168178. https://doi.org/10.1016/j.chb.2016.09.041

Kvasnicova, T., Kremenova, I., \& Fabus, J. (2016). From an analysis of e-services definitions and classifications to the proposal of new e-service classification. Procedia Economics and Finance, 39, 192-196. https://doi.org/10.1016/s2212-5671(16)30282-9

Lallmahomed, M. Z. I., Lallmahomed, N., \& Lallmahomed, G. M. (2017). Factors influencing the adoption of e-government services in Mauritius. Telematics and Informatics, 34(4), 57-72. https://doi.org/10.1016/j. tele.2017.01.003

Latan, H., \& Ghozali, I. (2016). Partial Least Square konsep, metode dan aplikasi menggunakan WarpPLS 5.0. Semarang: Badan Penerbit Universitas Diponegoro.

Mathiyarasan, M., \& Chitra, V. (2019). A study on customer awareness towards internet banking-with reference to Tumkurdistrict. SAARJ Journal on Banking \& Insurance Research, 8(3), 17-27. https://doi. org/10.5958/2319-1422.2019.00011.0
Mensah, I. K. (2018). Citizens' readiness to adopt and use e-government services in the city of Harbin, China. International Journal of Public Administration, 41(4), 297-307. https://doi.org/10.1080/01900692.2 016.1263658

Mota, F. P. B., Bellini, C. G. P., Souza, J. M. D. S., \& Oliveira, T. D. J. N. (2016). The influence of civic mindedness, trustworthiness, usefulness, and ease of use on the use of government websites. Revista de Administração, 51(4), 344-354. https://doi. org/10.1016/j.rausp.2016.07.002

Mustapha, B., \& Obid, S. N. B. S. (2015). Tax service quality: The mediating effect of perceived ease of use of the online tax system. Procedia - Social and Behavioral Sciences, 172, 2-9. https://doi. org/10.1016/j.sbspro.2015.01.328

Onu, D., \& Oats, L. (2018). Tax talk: An exploration of online discussions among taxpayers. Journal of Business Ethics, 149, 931-944. https://doi. org/10.1007/s10551-016-3032-y

Pitchay Muthu Chelliah, P., Thurasamy, R., Alzahrani, A. I., Alfarraj, O., \& Alalwan, N. (2016). E-government service delivery by a local government agency: The case of e-licensing. Telematics and Informatics, 33(4), 925-935. https://doi.org/10.1016/j.tele.2016.02.003

Prior, D. D., Mazanov, J., Meacheam, D., Heaslip, G., \& Hanson, J. (2016). Attitude, digital literacy and self efficacy: Flow-on effects for online learning behavior. The Internet and Higher Education, 29(April), 9197. https://doi.org/10.1016/j.iheduc.2016.01.001

Rajiani, I., \& Ismail, N. (2019). Management innovation in balancing technology innovation to harness universities performance in the era of Community 4.0. Polish Journal of Management Studies, 19(1), 309321. https://doi.org/10.17512/pjms.2019.19.1.24

Suryanto, T. L. M., Setyohadi, D. B., \& Faroqi, A. (2016). Analysis of the effect of information system quality to intention to reuse of employee management information system (Simpeg) based on information systems success model. MATEC Web of Conferences, 58, 1-6. https://doi.org/10.1051/ matecconf $/ 20165803001$

Widodo, M., Irawan, M. I., \& Sukmono, R. A. (2019). Extending UTAUT2 to explore digital wallet adoption in Indonesia. In 2019 International Conference on Information and Communications Technology (ICOIACT) (pp. 878-883). IEEE. 